\title{
A FEW OBSERVATIONS ON THE ADORNMENTS AND DRESS ACCESSORIES FOUND IN THE HOARD FROM ȚIFEŞTI (VRANCEA COUNTY)
}

\author{
Silviu Oța \\ Muzeul Național de Istorie a României, București \\ Calea Victoriei, no. 12, Sector 3 \\ RO - 030026 București \\ silviuota@yahoo.com
}

UDK / UDC: $903.8(498) " 14 "$

Izvorni znanstveni rad / Original scientific paper

https://doi.org/10.52064/vamz.54.1.27

Found by chance in 1912, the hoard from Țifești (in the former Putna County) immediately came to the attention of numismatists. First published in 1915 by Constantin Moisil, it remained in oblivion for a long time, at most barely mentioned in various articles. The beginning of the First World War and the entry of Romania in the middle of these events had, as a consequence, the evacuation of the country's treasure to Russia. After arriving in Moscow, it was returned to the Romanian state in 1956. The coins of the treasure came from both the Ottoman Empire and Hungary. The Turkish coins (the akçe) were issued during the reigns of Sultans Mehmed the Conqueror (1451 - 1481) and Bayezid II (1481 - 1512). The coins issued in Hungary are from

Key words:

Tifești, Vrancea County, Moldavia, Wallachia, Romania, treasure, earring, button, granulation, filigree, coin, silver

Found by chance in 1912, the hoard from Țifești (in the former Putna County) came relatively soon to the attention of numismatists. The hoard was first published in 1915 by Constantin Moisil, ${ }^{1}$ and a year later it was republished. ${ }^{2}$ After this, the hoard was relatively neglected until the 1960s, when it began to be mentioned again, usually in numismatic papers. ${ }^{3}$ Lately, atten- the time of kings Matthias Corvinus (1459 - 1490) and Vladislaus II (1490 - 1516). So far, they have not yet been published in full. The buttons (seven) are manufactured of filigree silver wire wrapped in the shape of a ball. The other two items, manufactured of foil, are dress accessories rather common in the Middle Ages, widely circulated both chronologically and territorially. There are also parts of buttons which are not mentioned in the article published in 1916. The adornments consist of two pairs of silver earrings manufactured in the filigree and granulation techniques. In the case of the items from Tifești, they are dated to the second half of the $15^{\text {th }}$ century.

tion has focused especially on the adornments ${ }^{4}$ and dress accessories. ${ }^{5}$ This situation is due to the less-than-common history of the hoard. The beginning of the First World War and the entry of Romania in the middle of these events had, as a consequence, the evacuation of the country's treasure to Russia, and the hoard from Țifești was among the evacuated items. The hoard re-

\footnotetext{
$1 \quad$ Moisil 1915 .

Moisil 1916

Moisil 1916; Iliescu 1968; Berciu-Drăghicescu 1989, 121, no. 95; 1990, 90, no 144; Popa, Nicolae 1992, 145, n. 7; Murgescu 1996, 327; Niculiță, Nicolae 1999; Nicolae 2003, 88; Alexiu, Martin 2008, 66; Butnariu 2017, nos 11, 155-156, 836, 1090, 1183, 1218, 1275, 1002; Tătaru 2019.
}

4 Artimon 2003, 182; Alaiba 2007a, 48; Oța 2012, 276, 280, Fig. 3: 13-14.
5 Oța et al. 2012, 140-141, 147, 151, Fig. 2, PI. 1: 5-11. 
mained in Moscow until 1956, when it was returned to the Romanian state. The ornaments and dress accessories were borrowed in the form of custody by the National Museum of Romanian History ${ }^{6}$ from the Romanian Academy?

Given that the number of archaeological discoveries of similar pieces has so far increased considerably, I believe it is important to resume the discussion on the adornments and the dress accessories found in the hoard. Based on the newly-discovered earrings and buttons from graves, treasure, settlements and stray finds, we can frame, more precisely from a chronological point of view, the earrings and buttons from Țifești, and we can also observe their area of distribution. Moreover, we can also better identify the origins of the decorative motifs and external influences on the local jewellery and the possible trade routes used to circulate the various items.

\section{Brief history of the hoard}

Its discovery is related to the replanting of a vineyard in the village of Țifești, on the property of N. Angonescu, near the River Putna, at a distance of 18 kilometres from the city of Focșani (currently in Vrancea County, or formerly in Putna County). ${ }^{8}$ According to the preserved information, it was found at a depth of 0.40 $\mathrm{m}$, in a hollowed stone covered with another stone. The hoard was purchased almost entirely by the Numismatics Cabinet of the Romanian Academy. It included coins $(384)^{9}$ as well as dress accessories and adornments.

The coins came from both the Ottoman Empire $(335)^{10}$ and Hungary (49). ${ }^{11}$ The Turkish coins (the akçe) were issued during the reigns of sultans Mehmed the Conqueror (1451 - 1481) and Bayezid II (1481 - 1512), and the coins issued in Hungary are from the time of kings Matthias Corvinus (1459 - 1490) and Vladislaus II (1490 - 1516). So far, they have not yet been published in full.

The adornments (Fig. 1) consist of two pairs of silver earrings manufactured in the filigree and granulation techniques (Fig. 2: A/3795-3796, 3793-3794; Fig. 3: 1-4), ${ }^{12}$ eight buttons made of filigree silver wire and decorated with granules (Fig. 2: 3801-3804, 3800, 3805, 3799; Fig. 3: 5-11) $)^{13}$ and another two of spherical shape with granules at the base (Fig. 1: upper-left and -right). It should be noted that the silver foil buttons, for unknown reasons, are not in the possession of the National Museum of Romanian History. Kept instead of them in the collections of MNIR are three halves of buttons manufactured by casting and decorated with plant motifs (Fig. 2: B/3797a-b, 3798; Fig. 3: 12-14), recorded as part of the hoard.

\footnotetext{
6 Hereafter: MNIR

Loan agreement no. 2699/31.05.1984, and the items were actually taken over with PV $2696 / 31.05$

I will not insist on all the details, as they have already been published by Constantin Moisil (1916)

Moisil 1916, 6

Moisil 1916, 6-7

Moisil 1916, 8-11.

Moisil 1916, 12-13

One of these was not found in the collections of MNIR
}

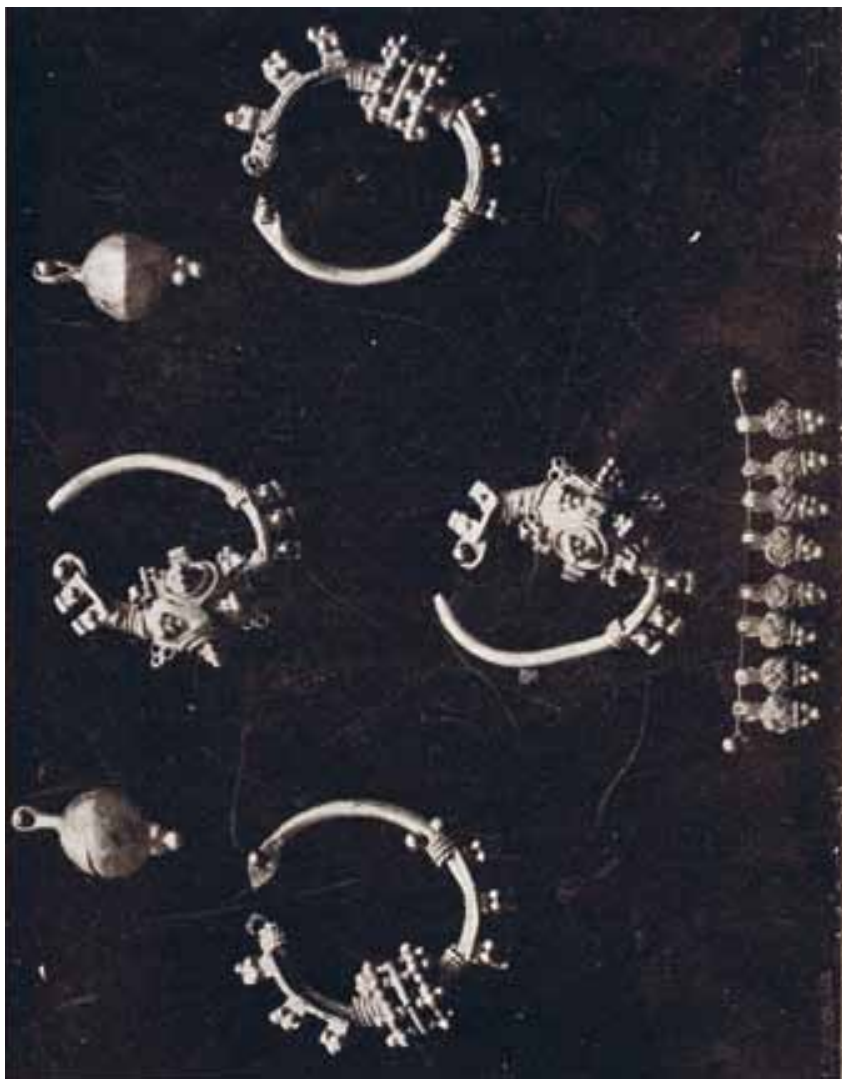

FIGURE 1. The illustration of the hoard published by Constantin Moisil in 1916 (Moisil 1916).

\section{Description of adornments}

1. Earring (MNIR, inv. no. C3795; Fig. 2: A/3795; Fig. 3: 2) manufactured of silver, decorated in the granulation and filigree techniques, with a central pendant (Fig. 2: A/3795/1) and two decorative plates (Fig. 2: A/3795/2-3) on either side of it. The link ( $D=32.7$ $\mathrm{mm} \times 26.2 \mathrm{~mm}$ ) is made of simple wire $(D=2.3 \mathrm{~mm})$, circular in section, with a flattened end (Fig. 4: upper), bent outwards in the shape of a loop. It is rectangular in section (Fig. 4: lower) in the areas where the decorative plates were mounted, on either side of the central pendant. The shape of the section was modified to allow a better fixing of the plates. The latter have different dimensions. The one near the loop end is shorter (length $=7.1 \mathrm{~mm}$; width $=8.2 \mathrm{~mm}$; height (ornament + plate) $=5.5 \mathrm{~mm}$ ) and is not curved alongside the link. It was decorated on the sides with two adjacent filigree wires $(2+2)$. Inside them are glued two groups of five small tubes made of simple, spiral wire (Fig. 2: A/3795/3; Fig. 5: centre). A silver granule is glued to the second row of small tubes. Towards the central pendant, eight filigree silver wire loops were wrapped up around the link. The second plate (length $=10.3 \mathrm{~mm}$; width $=8.0 \mathrm{~mm}$; height (ornament + plate $)=5.1$ $\mathrm{mm}$ ), slightly curved on the link, has decorations made similarly to those in the previous plate, but three in number. On the long sides there are two adjacent filigree wires $(2+2)$. At one end, on the outside, filigree silver wire was wrapped three times around the link. At the opposite side, towards the central pendant, the wire is wrapped eight times around the link. 
The central pendant is in the shape of an ellipsoid (length $=15.5$ $\mathrm{mm}$; D with ornament $=18 \mathrm{~mm}$ ), manufactured by casting. It has three triangular pyramids made of granules in its central area $(6+3+1)$. The base of each of them has, around it, two distanced concentric circles manufactured of filigree wire. Between the three granule pyramids and the small circles around them, the free area was decorated with three groups of three spiral wire tubes disposed in a triangular shape $(2+1)$. They were glued in the central area of the pendant. Between the central area and the ends of the ellipsoid, other groups of small spiral wire tubes were glued on its surface. Seen from the outside, together with the others in the central area, they represent a cross. Other granule pyramids (3) of similar dimensions to those in the middle area were glued between its arms. A perforation is observed on the surface of the pendant. The item was probably gilded. Traces of gold leaf can still be seen here and there.

2. Earring (MNIR, inv. no. C3796; Fig. 2: A/3796; Fig. 3: 1) manufactured of silver, decorated in the granulation and filigree techniques, with a central pendant (Fig. 2: A/3796/1) and two decorative plates, one on either side of it. In terms of decorative motifs, it is similar to the previous item. The link $(D=31.2 \mathrm{~mm})$ is made of simple wire $(D=2.3 \mathrm{~mm})$, circular in section, with a flattened end, bent outwards in the shape of a loop. Two rectangular plates were glued on it, similar to those on the previous item (Fig. 2: $\mathrm{A} / 3796 / 2$; length $=7.0 \mathrm{~mm}$; width $=8.0 \mathrm{~mm}$; height $=5.5 \mathrm{~mm} ;$ Fig. 2 : $\mathrm{A} / 3796 / 3$; length $=11.0 \mathrm{~mm}$; width $=7.7 \mathrm{~mm}$; height $=5.8 \mathrm{~mm}$ ). The second has a small tear. The central mount (length $=15.3 \mathrm{~mm} ; \mathrm{D}$ $=18.8 \mathrm{~mm}$ ) also has a perforation similar to that on the previous earring.

3. Earring (MNIR, inv. no. C3793; Fig. 2: A/3793/1; Fig. 3: 3) manufactured of gilded silver, with a pendant made of granules and with two decorative plates (Fig. 2: $A / 3793 / 2$ ) on either side of it. The link $(D=29.0 \mathrm{~mm})$ is made of wire, circular in section $(D=2.6 \mathrm{~mm})$ in the visible area and rectangular under the decorative plates. The wire was manufactured by hammering (Fig. 4: lower), as evidenced by the irregularities observable on its body. One end is flattened and bent outwards in the shape of a link, and the opposite end is rhombic, perforated in the centre. The first decorative plate is rectangular (length $=15.4 \mathrm{~mm}$; width $=9.3 \mathrm{~mm}$ ), bent in length according to the shape of the link. It was decorated with three groups of spiral wire tubes. Each group was formed of five such tubes $(3+2)$. On the long edges of the plate, two adjacent filigree wires were glued, forming a border. Two granules were glued at the top of each group. On the sides, between the tubes at the base and those in the second row, there are also two silver granules.

The second plate (length $=14 \mathrm{~mm}$; width $=8.7 \mathrm{~mm}$ ) is decorated similarly.

Between them and the central pendant $(D=12.7 \mathrm{~mm}$; width $=10.5$ $\mathrm{mm}$ ), but also at the end bent in the shape of a loop, filigree silver wire was wrapped up around the link (complete windings = $3+5+5+4)$ visible from the outside. Each of them usually continues with one or two partial windings.

The central pendant is formed of two parallel mouldings made of granules. Each of them has other spaced granules of the same size glued on the sides. A circular tube of spiral wire was glued between the mouldings and the spaced granules from the inside of the pendant (Fig. 5: upper).

Weight $=12.50 \mathrm{~g}$

4. Earring (MNIR, inv. no. C3794; Fig. 2: A/3794/1; Fig. 3: 4) manufactured of gilded silver, with a pendant made of granules and with two decorative plates, one on either side of it. The link (D $=28.6 \mathrm{~mm} / 32.1 \mathrm{~mm}$ ), slightly deformed, is made of wire circular in section $(D=2.6 \mathrm{~mm}$ ) in the visible area and rectangular under the decorative plates. One end is flattened and bent outwards in the shape of a link, and the opposite is rhombic, perforated at the centre. The first decorative plate is rectangular (length $=15.8$ $\mathrm{mm}$; width = $8.7 \mathrm{~mm}$; height (ornament + plate) $=6.1 \mathrm{~mm}$ ), bent in length according to the shape of the link. It was adorned with three groups of spiral wire tubes. Each group was formed of five such tubes $(3+2)$. Two adjacent filigree wires that form a border were glued on the long edges of the plate. Two granules were glued at the top of each group. On the sides, between the tubes at the base and those in the second row, there are also two silver granules.

The second plate (length $=15.2 \mathrm{~mm}$; width $=8.3 \mathrm{~mm}$; height (ornament + plate) $=6.00 \mathrm{~mm}$ ) is similarly decorated.

Between them and the central pendant $(D=13.2 \mathrm{~mm}$; width $=10.6$ $\mathrm{mm}$ ), and also at the end bent in the shape of a loop, filigree silver wire was wrapped up around the link (complete windings = $3+4+6+4)$ visible from the outside. Each of them usually continues with one or two partial windings.

The central pendant is formed of two parallel mouldings of granules. Each of them has other spaced granules of the same size glued on the sides. In total there are seven + seven groups of four granules (Fig. 6: upper and lower). A circular tube of spiral wire was glued between the mouldings and the spaced granules from the inside of the pendant $(D=1.4-1.5 \mathrm{~mm})$

Weight $=12.70 \mathrm{~g}$

\section{Description of dress accessories}

\section{A. Items published in $1916^{14}$}

1. Button (MNIR, inv. no. C3800; Fig. 2: A/3800; Fig. 3: row 3$)^{15}$ manufactured of filigree silver wire (length $=12.5 \mathrm{~mm}$, granule $D=1.8$ $\mathrm{mm}$, strap length $=2.3 \mathrm{~mm}$, strap width $=4.4 \mathrm{~mm}, \mathrm{D}=5.5 \mathrm{~mm}$; weight $=0.69 \mathrm{~g}$ ), wrapped up in the shape of a ball. (It has three parallel, adjacent filigree wires.) The strap has a longitudinal rib in the middle. At the base of the button there is a spiral wire moulding, on which three granules are glued on top of a fourth granule, thus forming a triangular pyramid. ${ }^{16}$

14 A button made of filigree wire and granules was not found in the collec tions of MNIR, so it cannot be described.

15 For the buttons belonging to this model, see Oța et al. 2012, 141, 151, PI 1: $5-11$.

16 Moisil 1916, 5, 13, PI. 1: lower; Oța et al. 2012, 141, 147, 151, Fig. 1, PI. 1: 6. 


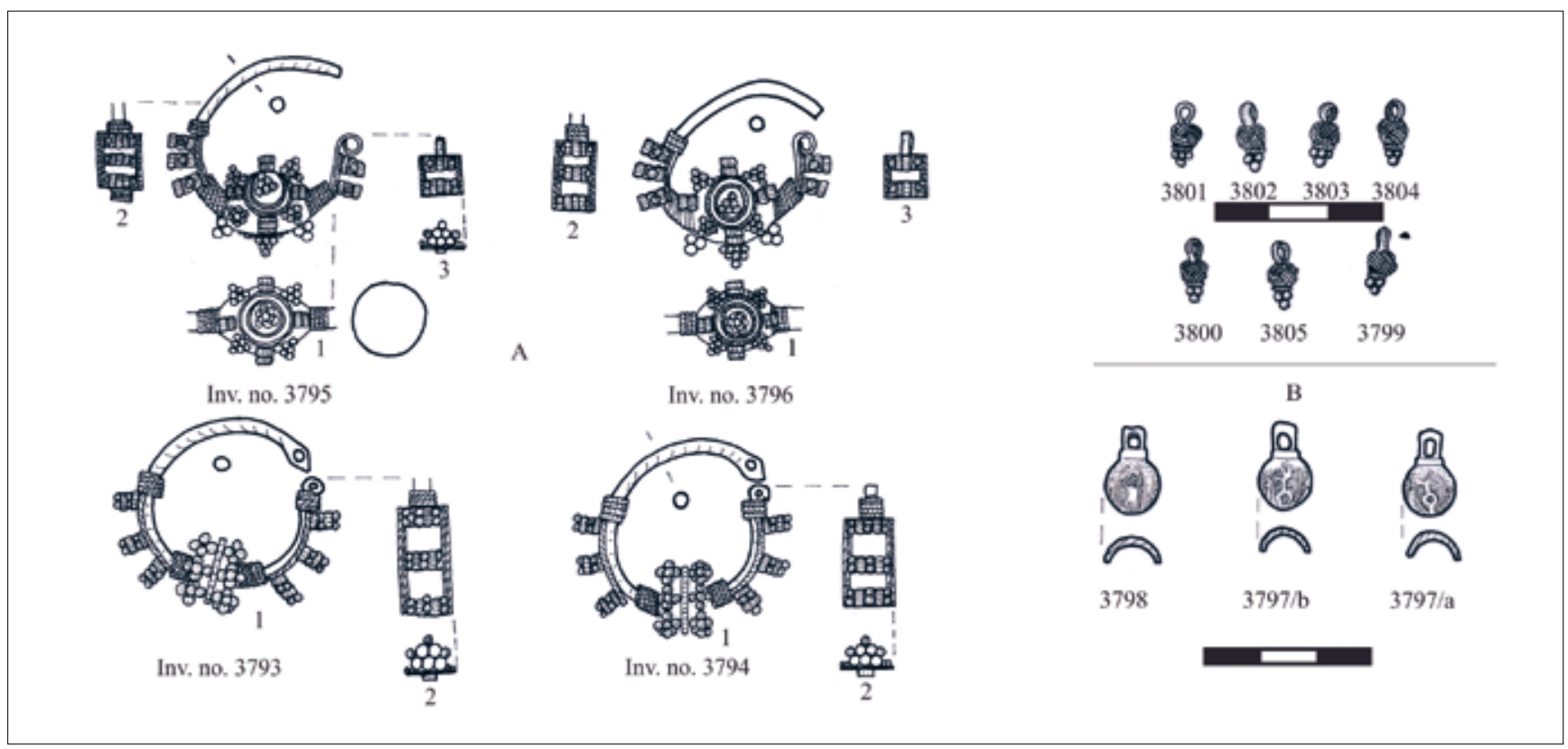

FIGURE 2. A: The items from the hoard at Țifești; B: Buttons that probably did not belong to the hoard (made by S. Mateescu).

2. Button (MNIR, inv. no. C3799; Fig. 2: A/3799; Fig. 3: row 3) manufactured of filigree silver wire (length $=12.7 \mathrm{~mm}$, granule $\mathrm{D}=1.6$ $\mathrm{mm}$, strap length $=4.2 \mathrm{~mm}$, strap width $=2.3 \mathrm{~mm}, \mathrm{D}=5.3 \mathrm{~mm}$; weight $=0.75 \mathrm{~g}$ ), wrapped up in the shape of a ball. (It has three parallel, adjacent filigree wires.) The strap has a longitudinal rib in the middle. At the base of the button there is a spiral wire moulding, on which three granules are glued on top of a fourth granule, thus forming a triangular pyramid. ${ }^{17}$

3. Button (MNIR, inv. no. C3803; Fig. 2: A/3803; Fig. 3: row 3) manufactured of filigree silver wire (length $=12.7 \mathrm{~mm}$, granule $\mathrm{D}=1.8$ $\mathrm{mm}$, strap length $=3.5 \mathrm{~mm}$, strap width $=2.4 \mathrm{~mm}, \mathrm{D}=5.2 \mathrm{~mm}$; weight $=0.68 \mathrm{~g}$ ), wrapped up in the shape of a ball. (It has three parallel, adjacent filigree wires.) The strap has a longitudinal rib in the middle. At the base of the button there is a spiral wire moulding, on which three granules are glued on top of a fourth granule, thus forming a triangular pyramid. ${ }^{18}$

4. Button (MNIR, inv. no. C3805; Fig. 2: A/3805; Fig. 3: row 3) manufactured of filigree silver wire (length $=12.4 \mathrm{~mm}$, granule $D=1.8$ $\mathrm{mm}$, strap length $=4.0 \mathrm{~mm}$, strap width $=2.2 \mathrm{~mm}, \mathrm{D}=5.3 \mathrm{~mm}$; weight $=0.69 \mathrm{~g}$ ), wrapped up in the shape of a ball. (It has three parallel, adjacent filigree wires.) The strap has a longitudinal rib in the middle. At the base of the button there is a spiral wire moulding, on which three granules are glued on top of a fourth granule, thus forming a triangular pyramid. ${ }^{19}$
5. Button (MNIR, inv. no. C3804; Fig. 2: A/3804; Fig. 3: row 3) manufactured of filigree silver wire (length $=12.1 \mathrm{~mm}$, granule $D=1.7$ $\mathrm{mm}$, strap length $=4.0 \mathrm{~mm}$, strap width $=2.1 \mathrm{~mm}, \mathrm{D}=5.7 \mathrm{~mm}$; weight $=0.74 \mathrm{~g}$ ), wrapped up in the shape of a ball. (It has three parallel, adjacent filigree wires.) The strap has a longitudinal rib in the middle. At the base of the button there is a spiral wire moulding, on which three granules are glued on top of a fourth granule, thus forming a triangular pyramid..$^{20}$

6. Button (MNIR, inv. no. C3801; Fig. 2: A/3801; Fig. 3: row 3) manufactured of filigree silver wire (length $=12.3 \mathrm{~mm}$, granule $\mathrm{D}=1.7$ $\mathrm{mm}$, strap length $=3.9 \mathrm{~mm}$, strap width $=2.2 \mathrm{~mm}, \mathrm{D}=5.3 \mathrm{~mm}$; weight $=0.71 \mathrm{~g}$ ), wrapped up in the shape of a ball. (It has three parallel, adjacent filigree wires.) The strap has a longitudinal rib in the middle. At the base of the button there is a spiral wire moulding, on which three granules are glued on top of a fourth granule, thus forming a triangular pyramid. ${ }^{21}$

7. Button (MNIR, inv. no. C3802; Fig. 2: A/3802; Fig. 3: row 3) manufactured of filigree silver wire (length $=12.3 \mathrm{~mm}$, granule $\mathrm{D}=1.8$ $\mathrm{mm}$, strap length $=4.0 \mathrm{~mm}$, strap width $=2.0 \mathrm{~mm}, \mathrm{D}=5.2 \mathrm{~mm}$; weight $=0.67 \mathrm{~g}$ ), wrapped up in the shape of a ball. (It has three parallel, adjacent filigree wires.) The strap has a longitudinal rib in the middle. At the base of the button there is a spiral wire moulding, on which three granules are glued on top of a fourth granule, thus forming a triangular pyramid. ${ }^{22}$
Moisil 1916, 5, 13, PI. 1: lower; Oța et al. 2012, 141, 147, 151, Fig. 1, PI. 1: 5. Moisil 1916, 5, 13, PI. 1: lower; Oța et al. 2012, 141, 147, 151, Fig. 1, PI. 1: 9. Moisil 1916, 5, 13, PI. 1: Iower; Oța et al. 2012, 141, 147, 151, Fig. 1, PI. 1: 11.
Moisil 1916, 5, 13, PI. 1: lower; Oța et al. 2012, 141, 147, 151, Fig. 1, PI. 1: 10. Moisil 1916, 5, 13, PI. 1: lower; Oța et al. 2012, 141, 147, 151, Fig. 1, PI. 1: 7. Moisil 1916, 5, 13, PI. 1: Iower; Oța et al. 2012, 141, 147, 151, Fig. 1, PI. 1: 8. 


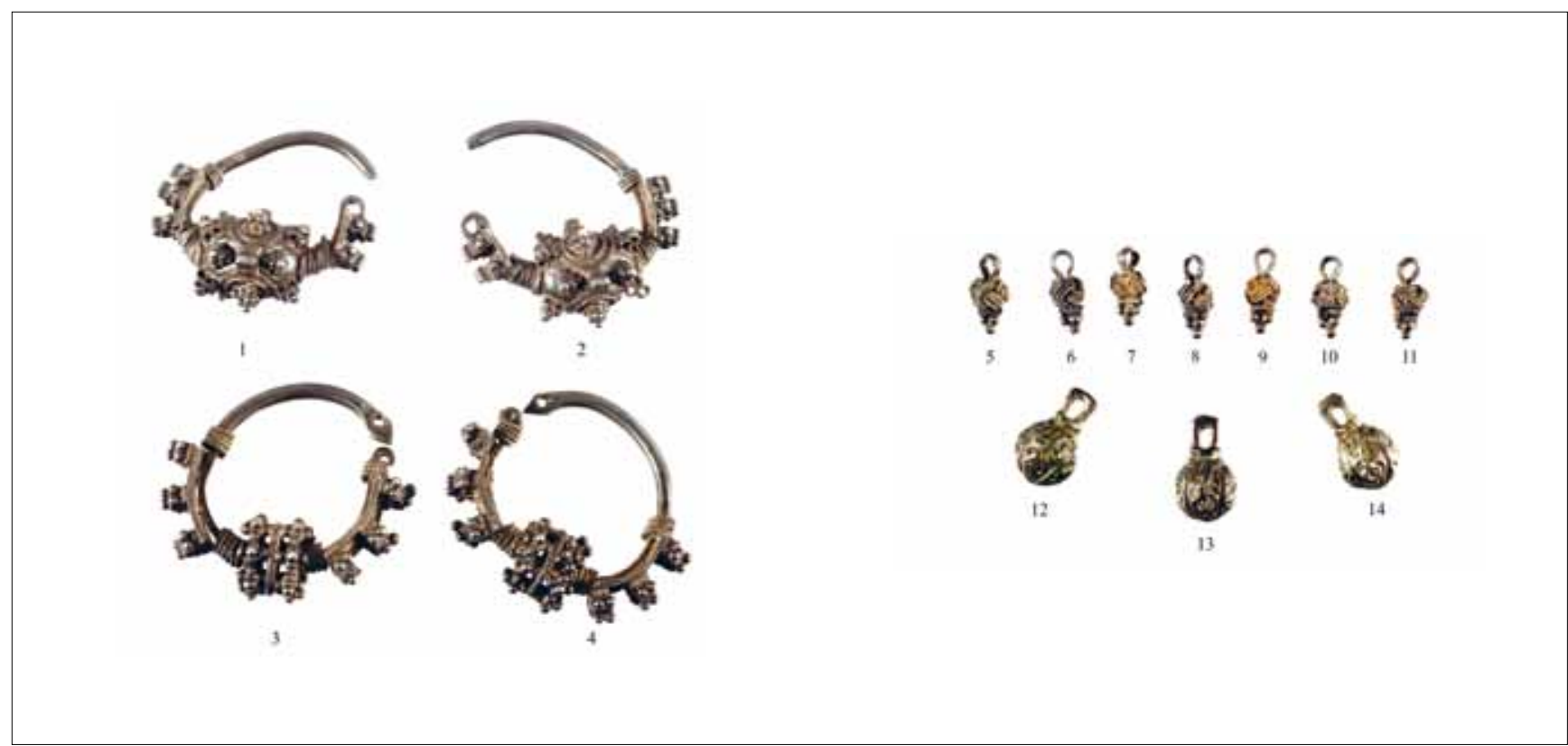

FIGURE 3. The items from the hoard at Țifești, as found today in the inventory register of MNIR (photo by M. Amarie).

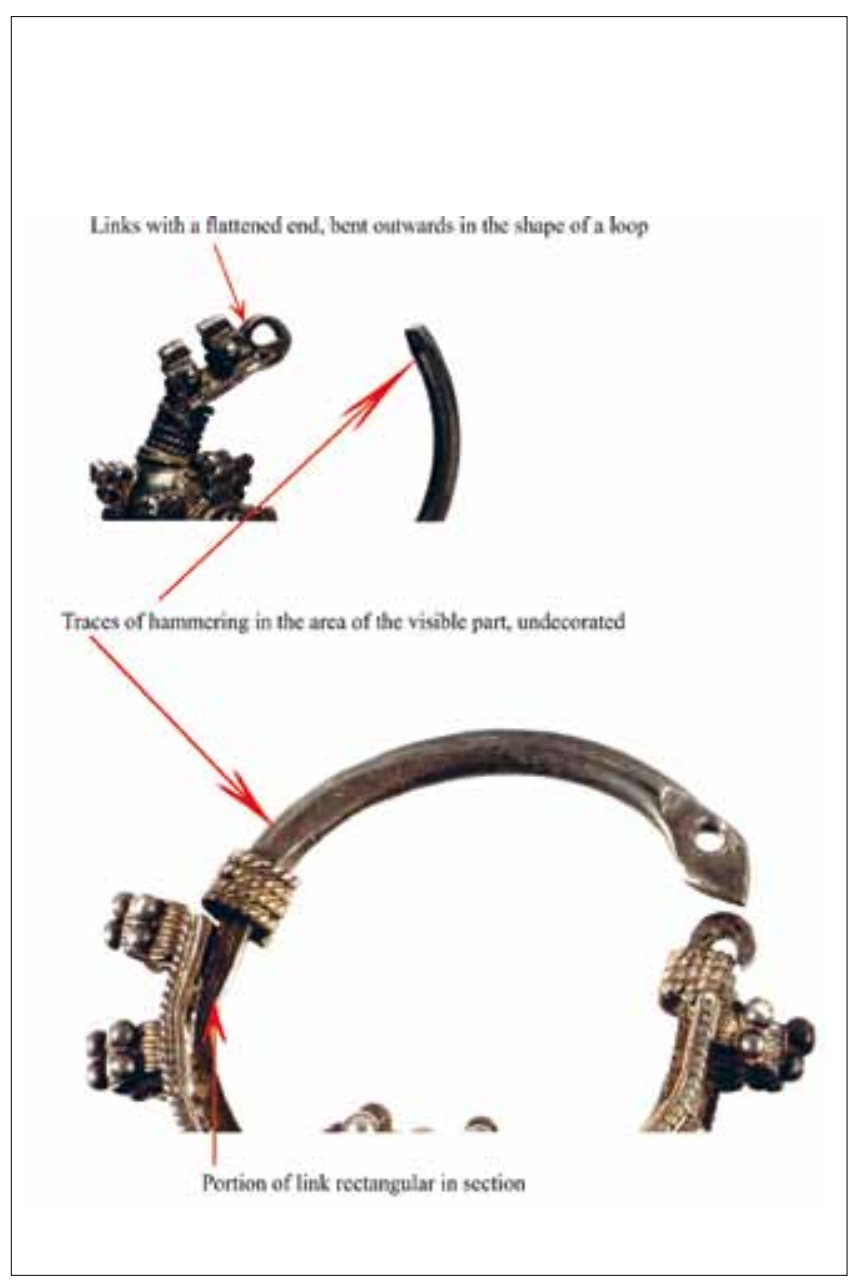

FIGURE 4. Details of manufacture of the earrings' links (photo by M. Amarie).

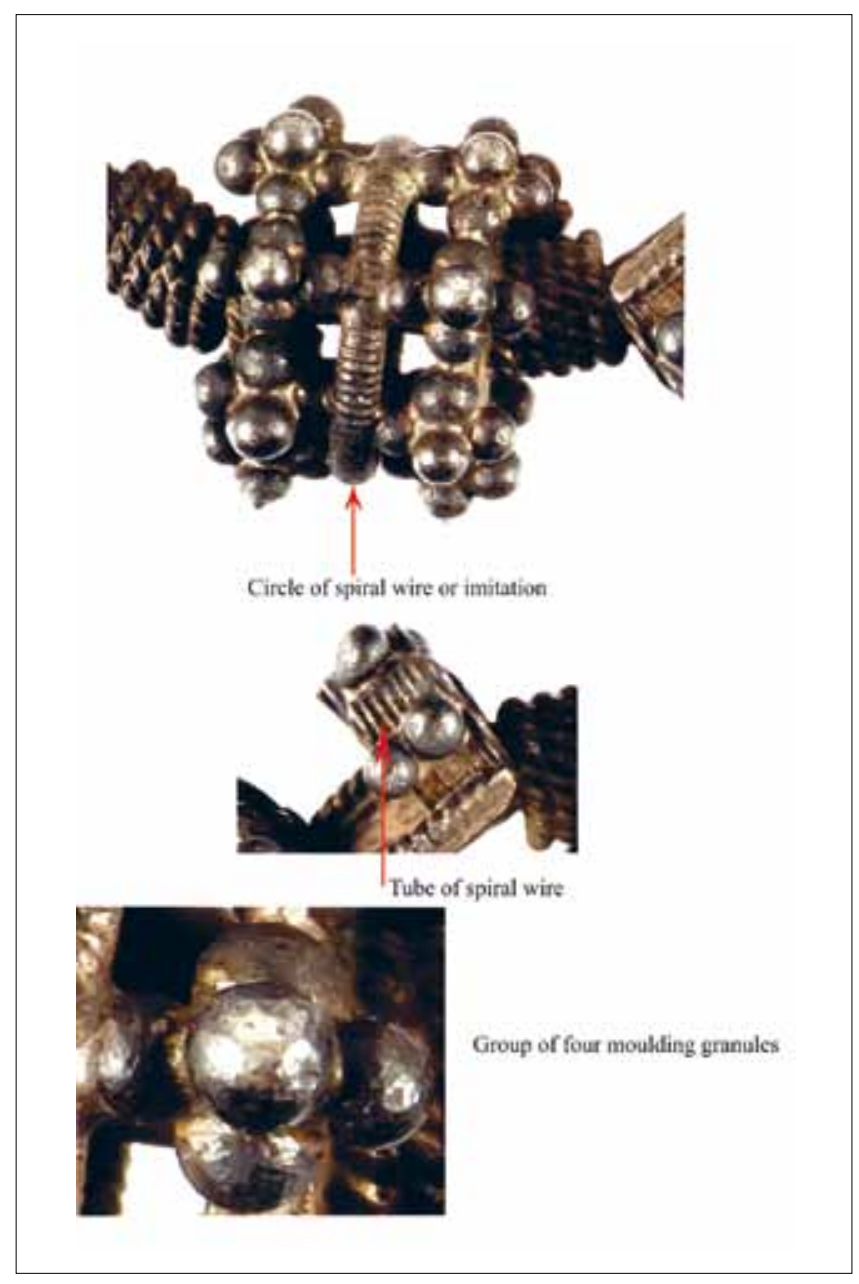

FIGURE 5. Earrings: detail of the central pendant and a side plate (photo by $M$ Amarie). 
FIGURE 6. Earrings: types of links similar to those of the items found in the hoard from Țifești

Yellow dot:

Links with a flattened end, bent outwards in the shape of a loop

Red dot:

Links with one rhombic end and the opposite one flattened and bent outwards in the shape of a loop (made by S. Oța, map provided by $\mathrm{M}$. Florea, SRTM-30).

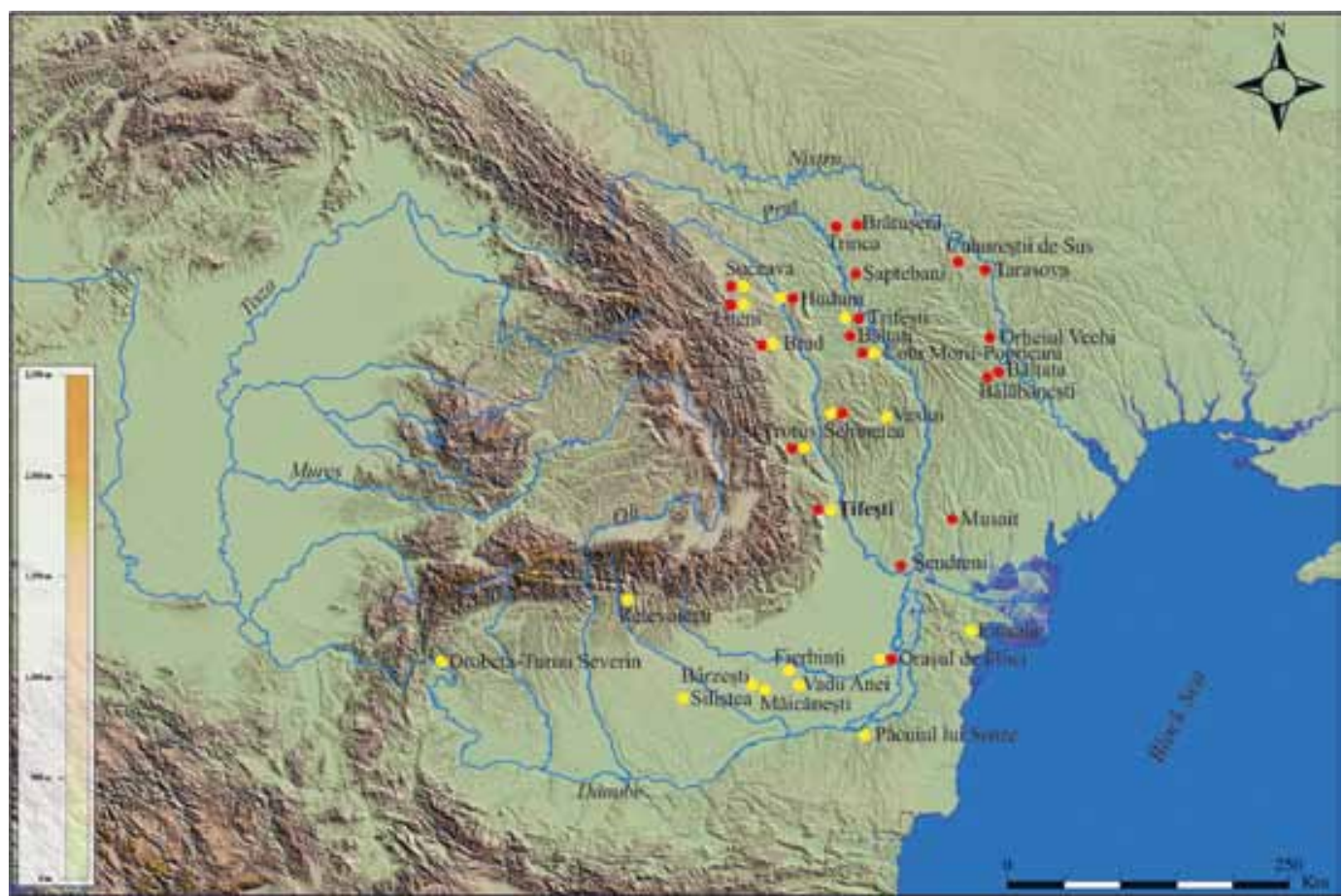

To the above-mentioned buttons could be added two spherical buttons made of silver foil (Fig. 1: upper-left and -right), decorated at the bottom with a pyramid of four granules $(D=6 \mathrm{~mm}$; weight $=1.85 \mathrm{~g}$ and $1.90 \mathrm{~g}$ ), and with the clamping link made of a silver band. ${ }^{23}$

\section{B. Items not mentioned in the article published in $1916^{24}$}

1. Half button (MNIR, inv. no. C3797/a; Fig. 2: B/3797/a; Fig. 3: 13) manufactured by casting (length $=15.7 \mathrm{~mm}, \mathrm{D}=9.7 \mathrm{~mm}$, height = $5.1 \mathrm{~mm}$ ). The strap is rectangular in shape and has a $4.9-\mathrm{mm}$ border at its base. It has a vegetal ornament.

2. Half button (MNIR, inv. no. C3797/b; Fig. 2: B/3797/b; Fig. 3: 14) manufactured by casting (length $=15.8 \mathrm{~mm}, \mathrm{D}=9.5 \mathrm{~mm}$, height = $4.5 \mathrm{~mm}$ ). The strap is rectangular in shape and has a $4.5-\mathrm{mm}$ border at its base. It has a vegetal ornament.

3. Half button (MNIR, inv. no. C3798; Fig. 2: B/3798; Fig. 3: 12) manufactured by casting (length $=15.7 \mathrm{~mm}, \mathrm{D}=9.7 \mathrm{~mm}$, height $=4.6$ $\mathrm{mm}$ ). The strap is rectangular in shape and has a $4.8-\mathrm{mm}$ border at its base. It has a vegetal ornament.

\section{Discussion}

Regarding the items from the Țifești hoard, I will firstly discuss the head adornments, more precisely the earrings, and then the dress accessories.

\section{The earrings ${ }^{25}$}

First of all, I will focus on the material they were made of and the shape of the link. The territorial distribution over the entire area of present-day Romania and the chronology of each type of link will be discussed. Then I will analyse the ornaments which are on either side of the central pendant (shape, manufacturing techniques, and ornamental motifs). Their dating will be based on those discoveries on the territory of present-day Romania in which similar items have been associated with coins. Finally, the central pendant will be analysed, taking into account the shape, manufacturing techniques, and ornamental motifs.

Since each type of earring is almost invariably a unique one, only those adornments that broadly have the same manufacturing and shape characteristics will be taken into account as analogies.

25 For the analogies, I shall only consider those items that have a simple wire link (with or without a rhombic perforated end), not twisted and with one flattened end, bent outwards.
23 Moisil 1916, 13, upper-left and -right.

24 Unpublished items. 


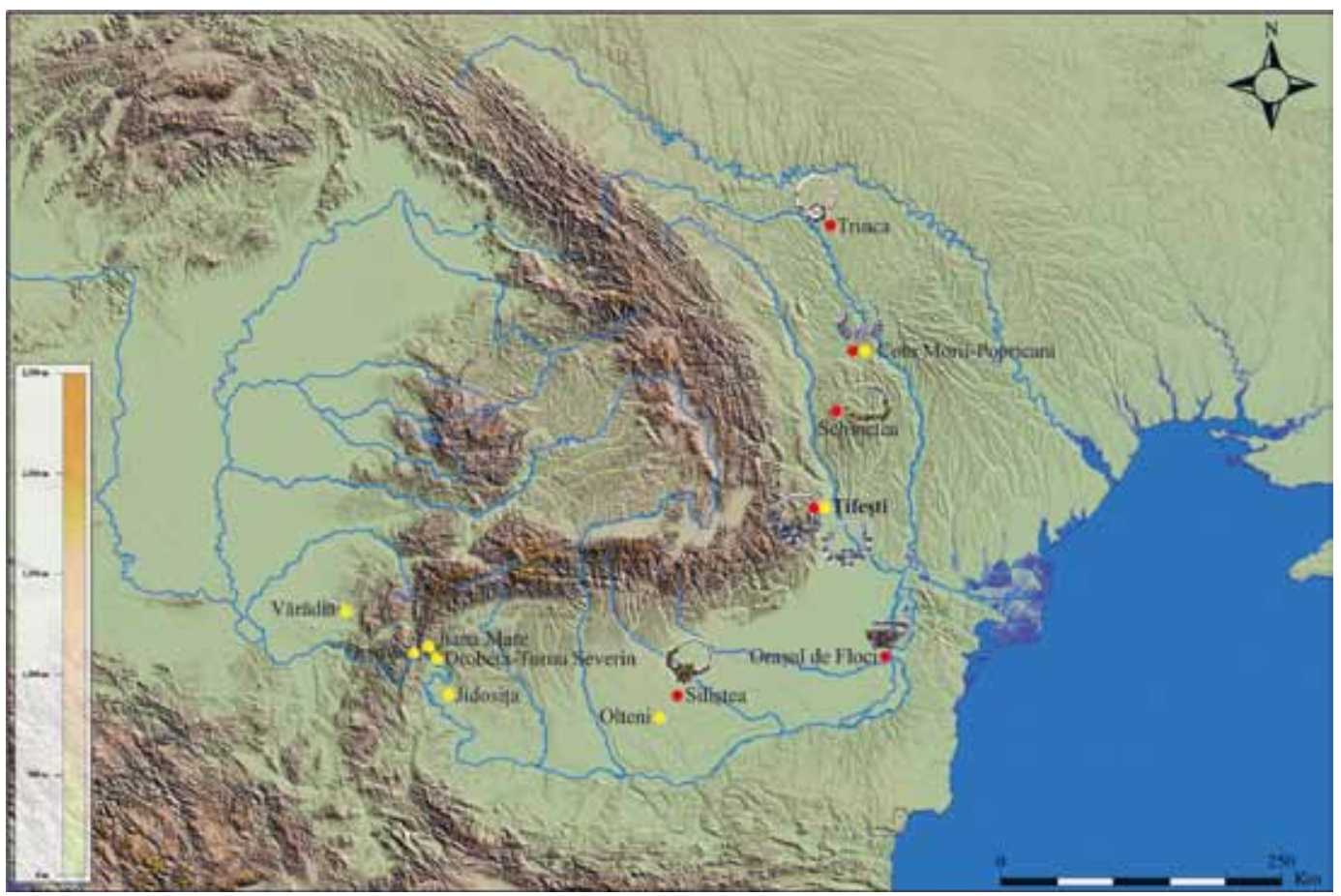

FIGURE 7. Map of the distribu tion of earrings with:

Yellow dot:

ellipsoidal pendants and dec orative plates

Red dot:

earrings with one or two rec tangular decorative plates and various pendants (Tifești, Siliștea, Schinetea, Trinca, Orașul de Floci-?; made by $\mathrm{S}$ Oța, map provided by M. Florea, SRTM-30)

\section{The links}

The first pair (Fig. 2/A/3795-3796; Fig. 3: 1-2) of earrings has a relatively simple link, with a flattened end, bent outwards in the shape of a loop (Fig. 6: the yellow dots). This type of link was widespread north of the Danube in the Middle Ages. It has been found in Moldavia in the cemeteries at Târgu Trotuș-"Țarna Nouă" (grave 37), ${ }^{26}$ Liteni-“Dealul Țiganului" (graves 61 and 58), ${ }^{27}$ Suceava"Câmpul Șanțurilor", ${ }^{28}$ Brad-"La Stâncă", ${ }^{29}$ and in the town of Suceava-“Cetatea de scaun”. ${ }^{30}$ In Wallachia it is known from the cemeteries at Retevoiești (grave 12),31 București-“Bârzești” (grave 34),,32 Străulești-“Măicănești” (grave 83),33 Vadu Anei (grave 313),,34 Fierbinți Târg-“Malu Roșu” (grave 6),35 Drobeta-Turnu Severin"Termele Romane", ${ }^{66}$ in the medieval towns of Orașul de Floci-"La Mănăstirea" ${ }^{37}$ and Târgșor, ${ }^{38}$ and from a chance find in Siliștea (Teleorman County). ${ }^{39}$ Similar items came from Dobruja, too, in the cemeteries at Enisala-"Burg" 40 and "Biserică", ${ }^{41}$ and Păcuiul lui Soare. ${ }^{42}$ This link type has been associated with two types of pendants (Fig. 7: red dots / Siliștea, Trifești). Its chronology is quite wide, from the $13^{\text {th }}$ century to the late $16^{\text {th }}$ century. At this stage of research, one may notice that the frequency of its use seems to have been higher in Wallachia and western Moldavia, while they are present only sporadically in eastern Moldavia.

The second pair link model (Fig. 6: the red dots) has an end bent in the shape of a loop, while the other has a rhombic shape, circularly perforated in the centre (Fig. 2: A/3793/1, 3794/1; Fig. 3: 3-4). One may easily notice that this model is most prevalent in Moldavia, in the cemeteries at Liteni-“Dealul Țiganului”, ${ }_{43}$ Suceava, ${ }^{44}$ Suceava-“Câmpul Șanțurilor”, ${ }^{45}$ Suceava-Burdujeni-“Siliște”, ${ }^{46} \mathrm{Hu}$ dum, ${ }^{47}$ Brad-"La Stâncă”, ${ }^{48}$ Trifești,49 Târgu Trotuș-“Țarna Nouă”, ${ }^{50}$ in the hoards from Schinetea, ${ }^{51}$ Bălțați,,52 Cuhureștii de Sus, ${ }^{53}$ Mu-

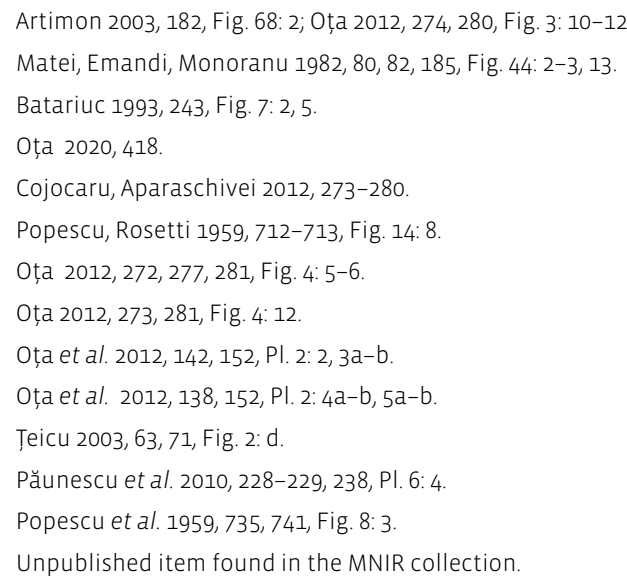

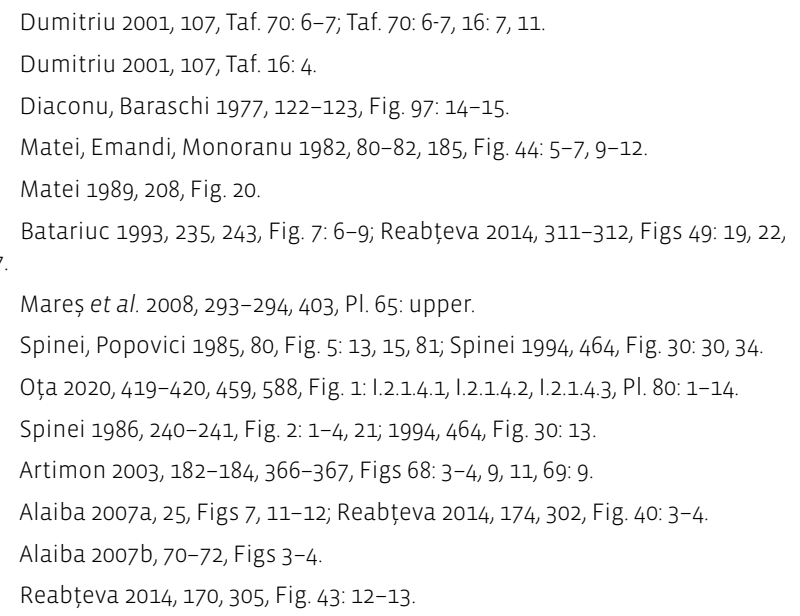


sait,, ${ }^{54}$ Bălăbănești, ${ }^{55}$ Brătușeni, ${ }^{56}$ Cotul Morii-Popricani, ${ }^{57}$ Bălțata, ${ }^{58}$ from the stray or unknown finds at Bârlad, ${ }^{59}$ Orheiul Vechi, ${ }^{60}$ Trinca, ${ }^{61}$ and from the settlements of Suceava-"Strada Curtea domnească, site 2", ${ }^{62}$ and Tarasova. ${ }^{63}$ Only one similar item was discovered in a cemetery in Wallachia, namely Orașul de Floci. ${ }^{64}$

\section{The decorative plates}

Decorative plates were fixed as ornaments on some earrings. Two shapes of such plates have been registered on the territory of the present-day Romania:

a. Rectangular, arched plates, decorated in one or several techniques (filigree, granulation, spiral wire tubes). Sometimes, the ornamentation of the earrings consists only in plates of this type; ${ }^{65}$ at other times the plates are combined with other ornaments, such as different types of pendants. Sometimes two decorative plates, flanking a central ornament, can be fixed on the earring.

Both pairs of earrings from Țifești were decorated with two such plates, but their central ornament differs: ellipsoidal pendant in the first pair (Fig. 2: A/3795/1, 3796/1) and pendant of parallel mouldings of granules in the second (Fig. 2: A/3793/1, 3794/1). The decorative plates of the first pair of earrings differ in dimensions, but the ornament is manufactured in the same techniques (filigree, granulation, spiral wire tubes). The long plates (Fig. 2: $\mathrm{A} / 3795 / 2,3796 / 2$ ) have three groups of spiral wires and granules, and the short one (Fig. 2: A/3795/3, 3796/3) only two. As for the second pair of earrings, the plates are similarly decorated, and have approximately the same length (Fig. 2: A/3793/2, 3794/2).

Such types of rectangular plates have been observed on earrings with ellipsoidal pendants found in the cemeteries at Orașul de Floci-“Cemetery no. 5” (grave 840)66 and Drobeta-Turnu Severin-
"Termele Romane" (grave 17), ${ }^{67}$ and in the hoards from Cotul Morii-Popricani, ${ }^{68}$ Schinetea $^{69}$ and Jidosița. ${ }^{70}$ In the case of earrings from Veliko Târnovo (Bulgaria), ${ }^{71}$ Trinca (chance find in the Republic of Moldavia) ${ }^{72}$ and Siliștea ${ }^{73}$ (Romania, Teleorman County), the rectangular plates were associated with other types of pendants.

The following coins were found associated with similar earrings in treasure (with rectangular plates): coins issued during the reign of Sultan Mehmed the Conqueror (1451 - 1481) and until the reign of Bayezid II (1481 - 1512) at Țifești; coins issued from the late $14^{\text {th }}$ century until $1461 / 71$ at Schinetea; coins issued during the reign of Matthias Corvinus (1458 - 1490) and until the reign of Suleiman I (1520 - 1566) at Cotul Morii-Popricani; coins issued during the reign of Radu I (c. 1377 - 1383) and until the reign of Mircea the Elder (1386 - 1418) at Jidosița. If we take into consideration the association with coins, it seems that earrings with rectangular, arched plates were in use between the end of the $14^{\text {th }}$ century and the beginning of the $16^{\text {th }}$ century. ${ }^{74}$ It is most likely that the manufacturing technique of such earrings did not exceed the beginning of the $16^{\text {th }}$ century, because such decorative motifs had gone out of fashion and been replaced by others. We can also note that such earrings were found associated in treasure either with coins dated up to the first two decades of the $15^{\text {th }}$ century, or with coins dated around the middle of the $15^{\text {th }}$ century, and up to the beginning of the $16^{\text {th }}$ century, with the exception of the Schinetea hoard. Taking into account the fact that earrings with double or triple mouldings have been discovered in graves dated to the $16^{\text {th }}$ century, too, the time span of their use can be extended. ${ }^{75}$ For instance, two earrings (one entirely preserved, and the other fragmentarily) were found in the medieval cemeteries of Drobeta-Turnu Severin (grave 17$)^{76}$ and Orașul de Floci. ${ }^{77}$ The cemetery at Drobeta-Turnu Severin is dated to between the second half of the $13^{\text {th }}$ century and the $15^{\text {th }}$ century. ${ }^{78}$ Cemetery no. 5 at Orașul de Floci was used between the $16^{\text {th }}$ and $18^{\text {th }}$ centuries.

\footnotetext{
54 Reabțeva 2014, 171, 300, Fig. 38: 5-6.

55 Reabțeva 2014, 167-169, 300, Fig. 38: 7, 9.

56 Reabțeva 2014, 185, 300, Fig. 38: 4

57 Neamțu 1961, 284, 286-287, Figs 1: 9, 3: 1.

58 Reabțeva 2014, 169, 307, Fig. 45: 1-7.

59 Item from the collections of the "Vasile Pârvan" Museum in Bârlad, Vaslui County. CIMEC site information - http://cimec.ro/, podoabă. cercel - INP, Bunuri culturale mobile clasate în Tezaurul Patrimoniului Cultural Național (23 November 2020).

60 Reabțeva 2014, 183, 313, Fig. 51: 1

61 Reabțeva 2014, 189, 300, Fig. 38: 2

62 Batariuc, Andronic 1993, 39-40, 61, Fig. 9: 3

63 Reabțeva 2014, 203, 306, Fig. 44: 4

64 Chițescu et al. 1979, 228, 233, Fig. 18: 8; Oța 2012, 273, 281, Fig. 4: 16; Reabțeva 2014, 323, Fig. 61: 11.

65 Suceava-“Câmpul Șanțurilor” (Batariuc 1993, 236, 243, Fig. 7: 7), Liteni"Dealul Țiganului" (Matei, Emandi, Monoranu 1982, 82, 185, Fig. 44: 5) and very probably Trinca (Reabțeva 2014, 166-167, 306, Fig. 44: 15-16). This type of ornament, with rectangular plates fixed on the link, was quite commonly used, especially in Moldavia, without other additional adornments on the link.

66 Unpublished item found in the MNIR (inv. no. 297137) collection. The graves of this cemetery are dated to the $16^{\text {th }}-18^{\text {th }}$ centuries (information provided by Anca Păunescu, whom I thank once again).
}

67 Bărcăcilă 1959, 781. The grave was dated to the $15^{\text {th }}$ century or first half of the $16^{\text {th }}$ (Dumitriu 2001, 122, Taf. 37: 8)

68 Neamțu 1961, 284,284, 286-287, Figs 1: 9, 13, 3: 1-2.

69 Alaiba 2007a, 24-25 Figs 10-11; Reabțeva 2014, 302, Fig. 40: 4.

70 Dumitriu 2001, 128, Taf. 96: 1, 4.

71 Павлова 2007, 25, cat. no. 2.1; Reabțeva 2014, 297, Fig. 35: 1-2.

72 Reabțeva 2014, 189, 300, Fig. 38: 2.

73 Unpublished item found in the MNIR collection.

74 In the current stage of research, no item that can be dated later than the early $16^{\text {th }}$ century is known in treasure or other types of discovery in Romania The latest items were found in association with the late $15^{\text {th }}$ century and early $16^{\text {th }}$. Serving as examples are the treasures from Schinetea and Cotul Morii-Popricani, where the latest issue is from 1520 (Neamțu 1961, 291).

75 Dumitriu 2006, 341-342, 346, 350, 355, 362, PIs 1: 3, 5, 8: M. 59; Păunescu, Teodor 2006, 296; Stancu 2006, 335, 339, PI. 1: 12 C-e, 13 b-c; Oța 2012, 275.

76 Bărcăcilă 1959, 780-781, Fig. 3: 7.

77 Chițescu et al. 1979, 228, 233, Fig. 18: 8; Oța 2012, 273, 281, Fig. 4: 16

78 Teicu 2003, 68. Alexandru Bărcăcilă submits another dating, between the $12^{\text {th }}$ and $16^{\text {th }}$ centuries (Bărcăcilă 1959, 775, 781). 
b. Rectangular plates with a circular end (found in the hoards from Olteni, ${ }^{79}$ Jiana Mare ${ }^{80}$ and Orșova), ${ }^{81}$ associated with the following coins: coins issued during the time of Mircea the Elder (1386 - 1418) at Orșova; coins issued during the time of Mircea the Elder (1386 - 1418) and Michael I (1418 - 1420) at Jiana Mare.

The territorial distribution of the discoveries seems to show two areas of circulation, namely Wallachia and southern medieval Hungary, and Moldavia. In the first case, the items from the area of western Wallachia and the Banate of Severin circulated simultaneously and were manufactured towards the end of the $14^{\text {th }}$ century and probably into the early $15^{\text {th }}$. Most of the coins were issued at the latest in the first quarter of the $15^{\text {th }}$ century. In these circumstances, we can suspect that most of the adornments in question belong especially to the $14^{\text {th }}$ century, regardless of the shape of the plates.

The earrings from Moldavia differ from those of western Wallachia and the Banate of Severin by their later dating (the earrings discovered in the hoard from Țifești, in the cemetery at Suceava"Câmpul Șanțurilor", ${ }^{2}$ and in the hoard from Cotul Morii-Popricani), and by the more diverse ornamentation of the central pendants.

\section{The central pendant}

Pair 1 (Fig. 2: A/3795/1, 3796/1) of earrings has a central pendant (Fig. 7: yellow dots) very similar to that of an earring discovered at Drobeta-Turnu Severin-“Termele Romane" (grave 17). ${ }^{83}$ Similar pendants, more or less ornamented, can be seen on the earrings from the treasures of Jidosița, Jiana Mare, Olteni and Orșova, and on an earring from Vărădia. ${ }^{84}$ If we take into account the chronology of the coins found in the south-Danubian treasures, this type of pendant seems to be used during the $14^{\text {th }}$ and early $15^{\text {th }}$ centuries. ${ }^{85}$ However, such earrings could have been manufac tured until the middle of the $15^{\text {th }}$ century, an assumption based on the chronology of the hoards from Cotul Morii-Popricani ${ }^{86}$ and Țifești. ${ }^{87}$

Most of the earrings decorated with ellipsoidal pendants are concentrated in western Oltenia (Jiana, Jidosița, Drobeta-Turnu Severin), eastern Banat (Vărădia, Orșova), eastern Serbia (Dobri Dol, Zaječar) and western Bulgaria (Gorna Bela Reška)..$^{88}$ Only one item was discovered in Wallachia, in the hoard from Olteni. However, the ornaments flanking the central pendant can differ from one earring to another. For the moment, pair 1 from Țifești and the fragment from Cotul Morii-Popricani ${ }^{89}$ are the only earrings from Moldavia decorated with a central ellipsoidal pendant and rectangular plates.

Pair 2 (Fig. 2: A/3793/1, 3794/1) of earrings has a central pendant made of double or triple granule mouldings. This type of pendant is quite well known in the Romanian space, ranging from the late $13^{\text {th }}$ century to the $16^{\text {th }}$ century. ${ }^{90}$ It was used both for earrings with simple or circular link, and for question-mark-shaped earrings. Its territorial distribution covers an extra-Carpathian area: the cemeteries of Suceava-Burdujeni-“Siliște", ${ }^{11}$ Drobeta-Turnu Severin-“Termele Romane”, Sucidava-Celei, Târgu Trotuș-“Ṭarna Nouă”, Nufăru-“Trecere Bac”, Enisala-“La Biserică”, Orașul de Floci-“Grindul 1-Biserica 2", București-“Bârzești”, Retevoiești, Străulești-“Măicănești”, Gruia, Vadu Anei, the settlement at Vaslui-“Curțile Domnești”, the hoards from Cotul Morii-Popricani and Olteni, and the earring from the collection of the Târgoviște museum (Wallachia). It is likely that it was sporadically used in the Banate of Severin, too. ${ }^{92}$

\section{The buttons}

The buttons are manufactured of filigree silver wire wrapped in the shape of a ball (Fig. 2: 3799-3805; Fig. 3: 5-11). I will not insist on their characteristics, as their full descriptions, including their chemical analysis, ${ }^{93}$ have been already published. ${ }^{94}$ Similar items

\footnotetext{
79 Rosetti 1972, 9-10, 12-13, Figs 23, 25; Oța 2011, 237-238, 247, PI. 2: 4-7.

80 Dumitriu 2001, 127, Taf. 39: 1-2, 2a, 4-5, 5 a.

81 Réthy 1892, 433-436; Rosetti 1972, 10, 14, Fig. 30.

82 This one was attached to another link model, and the central pendant is polyhedral. This is proof that the decorative plates began to be used on other models of earrings that were in use until the $16^{\text {th }}$ century and even the $17^{\text {th }}$.

83 Bărcăcilă 1959, 780-781, Fig. 3: 7

84 Oța 2011, 233-250.

85 Oța 2011, 242
}

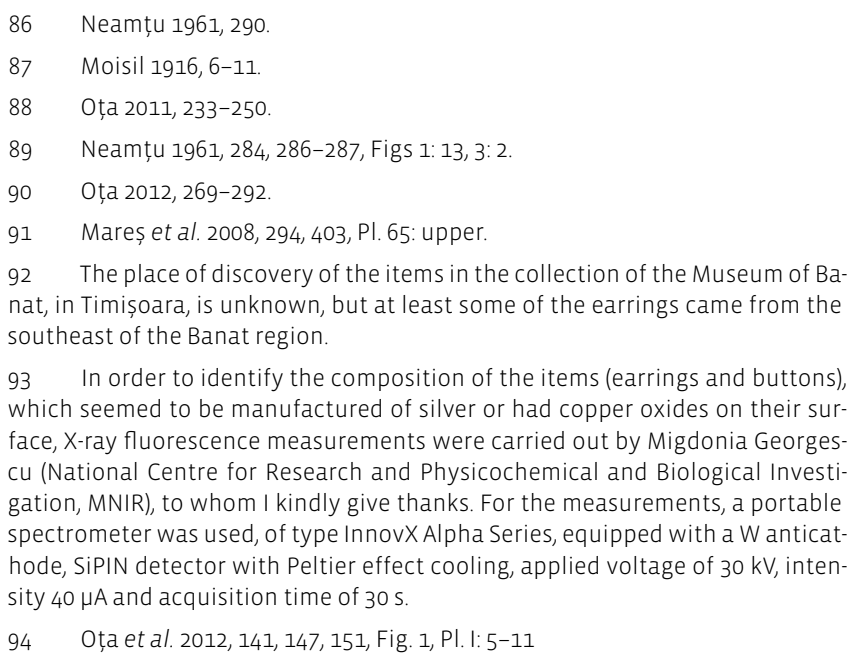
nat, in Timișoara, is unknown, but at least some of the earrings came from the southeast of the Banat region.

In order to identify the composition of the items (earrings and buttons) which seemed to be manufactured of silver or had copper oxides on their surface, X-ray fluorescence measurements were carried out by Migdonia Georgescu (National Centre for Research and Physicochemical and Biological Investigation, MNIR), to whom I kindly give thanks. For the measurements, a portable spectrometer was used, of type InnovX Alpha Series, equipped with a W anticathode, SiPIN detector with Peltier effect cooling, applied voltage of $30 \mathrm{kV}$, intensity $40 \mu \mathrm{A}$ and acquisition time of $30 \mathrm{~s}$

94 Oța et al. 2012, 141, 147, 151, Fig. 1, PI. I: 5-11 
have been discovered especially outside the Carpathian Arc, at Orașul de Floci-“Cemetery no. 5” (grave 841), ${ }^{95}$ Zăvoaia, ${ }^{96}$ Târgu Trotuș.“Ṭarna Nouă” (grave 106), ${ }^{97}$ and Baia. ${ }^{98}$

Besides buttons, this decoration made of wires wrapped in the shape of a ball was also used to decorate earrings, such as for the items discovered at Vadu Anei (grave 76), ${ }^{99}$ Orașul de Floci (graves 59 and 64), ${ }^{100}$ București-“Biserica Sf. Dumitru-Poștă” (grave 162), ${ }^{101}$ Liteni-“Dealul Țiganului” (grave 55), ${ }^{102}$ Brad-“La Stâncă”, ${ }^{103}$ Orheiul Vechi,, ${ }^{104}$ Tarasova, ${ }^{105}$ and Netezi-“Brătulet” (grave 31). ${ }^{106}$ This technique was rather widely used, but some of the pendants were not manufactured of filigree wire. ${ }^{107}$

Sometimes, the buttons were made of textile materials, such as the fragments identified in the cemetery at Gruia (Mehedinți County), ${ }^{108}$ dated to the $14^{\text {th }}$ and $15^{\text {th }}$ centuries.

The origin of the ornament consisting in wire wrapped in the shape of a ball is quite difficult to establish. For the time being, this type of ornament was used both for buttons and earrings, and it is documented only in the extra-Carpathian area, and sporadically to the south of the Danube, such as in Novo Brdo (Cathedral, Saška church), ${ }^{109}$ Kolubarski Leskovac-Ćetenište, Požarevac-Nad-Lugom, ${ }^{110}$ but it is also attested in the Russian space and Ukraine. ${ }^{111}$

The other two buttons (Fig. 1: upper-left and -right) manufactured of foil are dress accessories rather common in the Middle Ages, widely circulated both chronologically and territorially. The decoration of the lower part, manufactured in the granulation technique in the shape of a three-sided pyramid, is however a bit less common in the North-Danube area. Such buttons were also discovered in the hoards from Covei (Oltenia) ${ }^{112}$ and Dubo- vac (the Serbian Banat), ${ }^{113}$ at Kaliakra ${ }^{114}$ (Bulgaria), and also in the area of Naprelje, ${ }^{115}$ Novo Brdo, ${ }^{116}$ Glogovik, ${ }^{117}$ Ritopek, ${ }^{118}$ Postenje, ${ }^{119}$ and Novi Pazar-Deževa ${ }^{120}$ (Serbia). One may notice that these items seem to originate mainly from the southern part of Serbia, where most of these finds are concentrated. Interestingly, so far, they have yet not been discovered in Macedonia, and are only sporadically found in Bulgaria. Their chronology is quite wide, as they are dated to the $14^{\text {th }}$ century (Kaliakra), ${ }^{121} 16^{\text {th }}$ century (Novo Brdo) 122 and even $17^{\text {th }}$ to $18^{\text {th }}$ century (Dubovac). Buttons ornamented with pyramids with four granules were in use especially in the $15^{\text {th }}$ and $16^{\text {th }}$ centuries (for example, the treasure from Cândești, ${ }^{123}$ Schinetea ${ }^{124}$ and Zăvoaia, ${ }^{125}$ or the cemeteries at Suceava-"Câmpul Șanțurilor" ${ }^{126}$ and Strei)127 in Wallachia, Moldavia and southern Transylvania.

Button halves manufactured by casting (Fig. 2: B/3797/a-b, 3798; Fig. 3: 12-14) have been discovered in the extra-Carpathian area only in Tarasova ${ }^{128}$ and Orașul de Floci, ${ }^{129}$ and are dated to the $15^{\text {th }}$ - $16^{\text {th }}$ centuries. ${ }^{130}$ The rarity of these buttons could suggest that they were items not locally manufactured, but rather imported.

\section{Conclusions}

Except for the three halves of cast buttons, the Tifești hoard is composed of quite common items for the eastern and southern Carpathian areas. The central pendant of the earrings of pair 1 has analogies in western Wallachia; the link has analogies in Wallachia and western Moldavia; and the rectangular plates characterize the earrings of Moldavia and eastern Wallachia, being only accidentally found in western Oltenia, at Drobeta-Turnu Severin. The central pendant of the earrings of pair 2 has analogies in the eastern and southern Carpathian areas, and in the Banat, too; the link seems to be characteristic of earrings found in

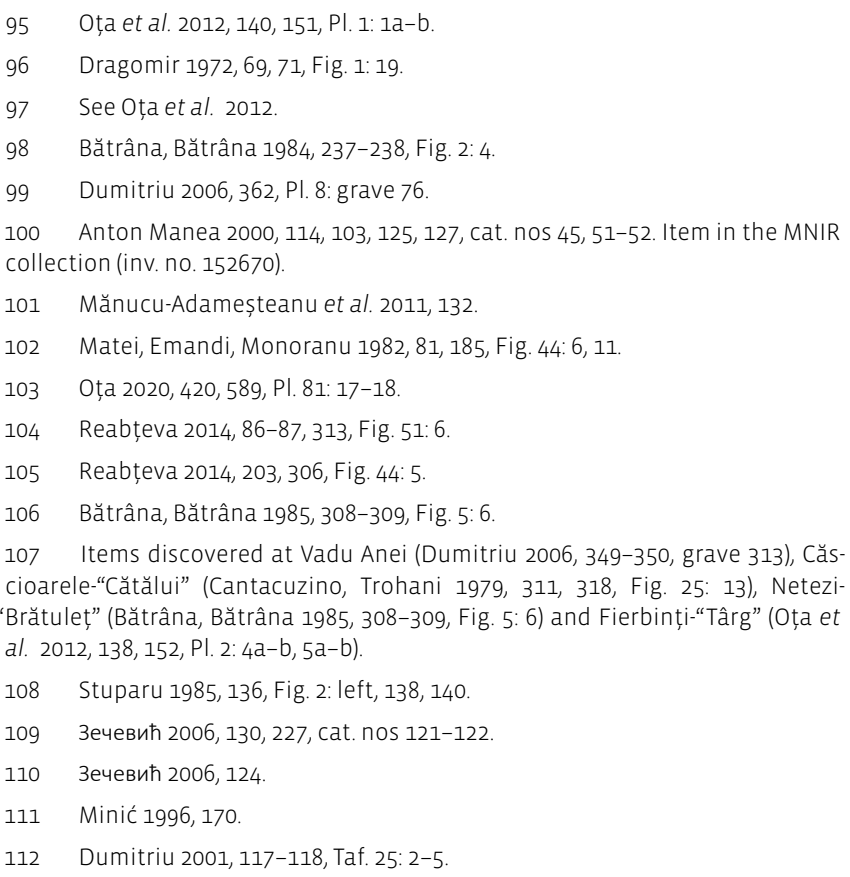

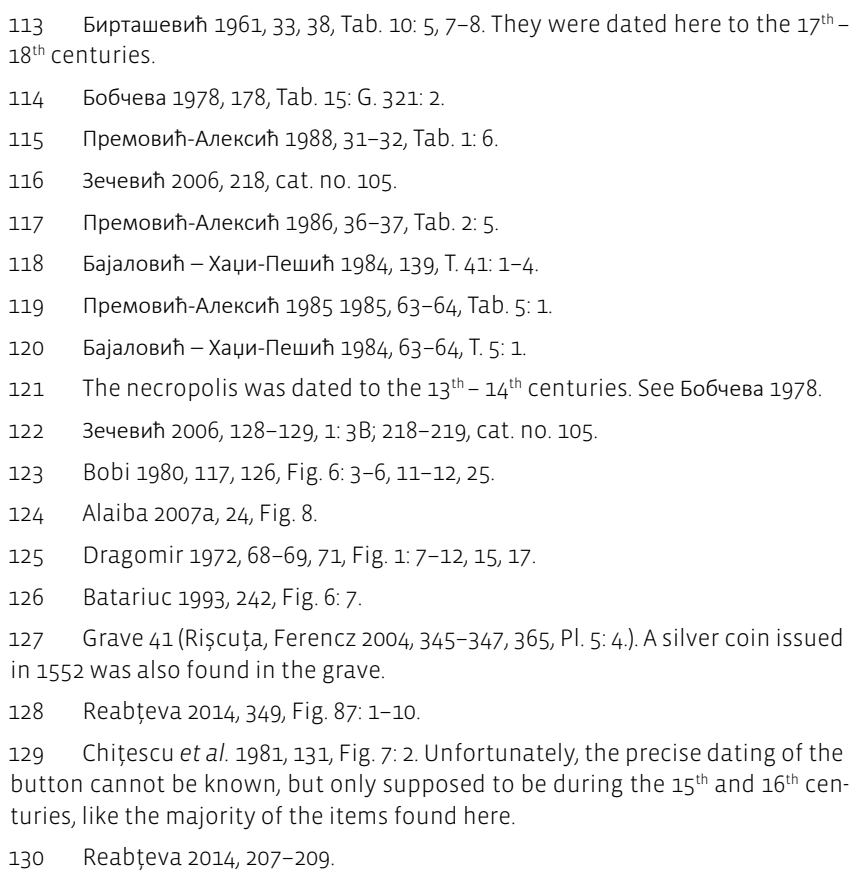


Moldavia, and only accidentally in eastern Wallachia (Orașul de Floci); and the side plates are often discovered in Moldavia.

At first sight, the spherical buttons made of silver foil seem to be common accessories. What sets them apart from other buttons is the decoration of the lower part, consisting of granules, which is relatively rare and was used especially during the $15^{\text {th }}$ and $16^{\text {th }}$

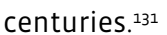

The buttons made of filigree wire, decorated with pyramids of granules, can be dated to the $15^{\text {th }}$ and $16^{\text {th }}$ centuries, too. They seem to represent one of the dress accessories typical of areas outside the Carpathian Arc, and of the Balkan region.

131 We have two exceptions at Târgu Trotuș and, probably, Orașul de Floci (see Oța et al. 2012, 140, 145).
In my opinion, the cast buttons cannot belong to the Țifești hoard, although their dating does not differ from that of the other items found in the treasure.

To sum up, the items from the Țifești hoard are adornments and dress accessories specific to Moldavia, with some elements common to the Wallachian area. Far from being a surprise, these mixed characteristics can be explained by the fact that the Tifești hoard was found not far from the border between Wallachia and Moldavia.

\section{BIBLIOGRAPHY}

Alaiba 2007a - R. Alaiba, 2. Schinetea, comm. de Dumești, dép de Vaslui; 1982, in Butnariu, V. M. (ed.), Monnaies et parures du Museé Départamental Ștefan Mare de Vaslui, Pamfilius, 2007, 15-53.

Alaiba 2007b - R. Alaiba, Bălțați, comm. de Tătărani, dép. de Vaslui; 1998. A. Parrures de corps, in Butnariu, V. M. (ed.), Monnaies et parures du Museé Départamental Ștefan cel Mare de Vaslui, Pamfilius, 2007, 57-89.

Alexiu, Martin 2008 - A. Alexiu, Al. Martin, Cercetări numismatice - 1978 2007. Sumarul și indicele pe materii, Cercetări Numismatice 14, 2008, 17-146.

Anton Manea 2000 - C. Anton Manea, Podoabe și accesorii vestimentare des coperite la Orașul de Floci între 1975 - 1989, Ialomița 3, 2000, 97-139.

Artimon 2003 - Al. Artimon, Orașul medieval Trotuș în secolele 14 - 17. Geneză și evoluție, Corgall Press, 2003.

Бајаловић - Хаџи-Пешић 1984 - М. Бајаловић - Хаџи-Пешић, Накит 8- 18 века у Музеју града Београда, Музеј града Београда, 1984.

Batariuc 1993 - P. V. Batariuc, Necropola medievală de la Suceava - Câmpul Șanțurilor, Arheologia Moldovei 16, 1993, 229-249.

Batariuc, Andronic 1993 - P. V. Batariuc, M. Andronic, Descoperiri arheologice la Suceava - contribuții la cunoașterea topografiei orașului medieval, Suceava. Anuarul Muzeului Bucovinei 17-19, 1993, 36-61.

Bărcăcilă 1959 - Al. Bărcăcilă, Monede, podoabe și fragmente ceramice de la termele Drubetei și din cimitirul medieval suprapus, Materiale și Cercetări Arheologice 5, 1959, 769-785

Bătrâna, Bătrâna 1984 - L. Bătrâna, A. Bătrâna, Contribuții arheologice la istoricul orașului Baia, Cercetări Arheologice 7, 1984, 230-243.

Bătrâna, Bătrâna 1985 - L. Bătrâna, A. Bătrâna, Reședința feudală de la Netezi (jud. Neamț), Studii și Cercetări de Istorie Veche (și Arheologie) 36/4, 1985, 297315 .
Berciu-Drăghicescu 1989 - A. Berciu-Drăghicescu, Repertoriul descoperirilor monetare otomane din teritoriile locuite de români în secolele 15 - 16, Caietul seminarului special de științe auxiliare ale istoriei 1, 1989, 88-124.

Berciu-Drăghicescu 1990 - A. Berciu-Drăghicescu, Repertoriul descoperirilor monetare de pe teritoriul Moldovei (secolele 14 - 16), Caietul seminarului spe cial de științe auxiliare ale istoriei. Opuscula bibliologica, genealogică, numis matică 2, 1990, 54-92,

Бирташевић 1961 -М. Бирташевић, Збирка средњевековног и касног народног накита из Дубовца, Рад Војвођанских Музеја 10, 1961, 25-48.

Бобчева 1978 - Л. Бобчева, Некропол от 13 - 14 век в Калиакра, Известия на Народния музей Варна 14 (24), 1978, 152-180.

Bobi 1980 - V. Bobi, Tezaurul medieval de monede și podoabe descoperit la Cîndești-Vrancea, Studii și Comunicări 3, 1980, 111-126.

Butnariu 2017 - V. M. Butnariu, Bibliografie numismatică pentru Moldova. 1359 - 1859, seria Moneta Terrae Moldaviae - I, Ștef, 2017.

Cantacuzino, Trohani 1979 - Gh. Cantacuzino, Gh. Trohani, Săpăturile arheologice de la Cătălui-Căscioarele, jud. Ilfov, Cercetări Arheologice 3, 1979, 261-368.

Chițescu et al. 1979 - L. Chițescu, N. Conovici, R. Lungu, A. Păunescu, V. RădulesCu, Cercetări arheologice la Piua Petrii (Orașul de Floci), jud. Ialomița, Cercetări Arheologice 3, 1979, 199-246.

Chițescu et al. 1981 - L. Chițescu, R. Lungu, T. Papasima, P. Vlădilă, V. Rădulescu, A. Păunescu, Cercetări arheologice în anul 1979 la Piua Petri (Orașul de Floci) comuna Giurgeni, jud. Ialomița, Cercetări Arheologice 4, 1981, 120-143.

Cojocaru, Aparaschivei 2012 - I. Cojocaru, C. Aparaschivei, Formă și imagine: Intervenții de restaurare asupra unei bijuterii medievale, Suceava. Anuarul Muzeului Bucovinei 39, 2012, 273-280. 
Diaconu, Baraschi 1977 - P. Diaconu, S. Baraschi, Păcuiul lui Soare. Așezarea medievală (secolele 13 - 15) 2, Editura Academiei, 1977

Dragomir 1972 - I. T. Dragomir, Tezaurul de la Zăvoaia (jud. Brăila), Buletinul Monumentelor Istorice 41/2, 1972, 67-73.

Dumitriu 2001 - L. Dumitriu, Der mittelalterliche Schmuck des Unteren Don augebietes im 11.-15. Jahrhundert, Editura Muzeului Național de Istorie a României, 2001.

Dumitriu 2006 - L. Dumitriu, Objets de parure de la nécropole de Valu Anei, Cercetări Arheologice 13, 2006, 341-362.

Iliescu 1968 - O. Iliescu, Notes de numismatique orientale, Studia et Acta Orientalia 7, 1968, 260-261.

Mares et al. 2008 - I. Mares, B. P. Niculică, St. Dejan, S. Bedreagă, T. Dolenschi, 167. Suceava, jud. Suceava. Punct: Cartier Burdujeni, Siliște (pepinieră), in Angelescu, M. V., Vasilescu, F. (eds.), Cronica Cercetărilor Arheologice din România. Campania 2007. A XLII-a Sesiune Națională de Rapoarte Arheologice, Iași, 14-16 mai, 2008, CIMEC - Institutul de Memorie Culturală, 2008, 293-294, 403.

Matei 1989 - M. D. Matei, Civilizație urbană medievală românească. Contribuții (Suceava pînă la mijlocul secolului al XVI-lea), Editura Academiei, 1989.

Matei, Emandi, Monoranu 1982 - M. D. Matei, E. I. Emandi, O. Monoranu, Habitatul medieval rural din bazinul Șomuzului Mare și al Moldovei (secolele 14 - 17), Muzeul Județean Suceava, 1982.

Mănucu-Adameșteanu et al. 2011 - Gh. Mănucu-Adameșteanu, A. E. Boroneanț, A. Măgureanu, R. I. Popescu, Arheologia credinței, Cercetări arheologice la bi serici bucureștene, Istoria orașului București 4/1, Mistral Info Media - Semne, 2011

Minić 1996 - D. Minić, Nouvelle variante de boucles d'oreille médiévales à trois fraises en Serbie, Starinar 47, 1996, 169-175

Moisil 1915 - C. Moisil, Academia Română, Creșterea Colecțiunilor 27, 1915 199-202.

Moisil 1916 - C. Moisil, Monete și podoabe de la sfârșitul secolului al XV-lea (Tezaurul de la Țifești, jud. Putna), Buletinul Societății Numismatice Române $27,1916,3-16$.

Murgescu 1996 - B. Murgescu, Circulația monetară în țările Române în secolul al XVI-lea, Biblioteca Băncii Naționale 16, Editura Enciclopedică, 1996

Neamțu 1961 - E. Neamțu, Obiectele de podoabă din tezaurul medieval de la Cotul Morii, Popricani (Iași), Arheologia Moldovei 1, 1961, 283-293.

Nicolae 2003 - E. Nicolae, Moneda otomană în țările Române în perioada 1451 -1512, ARC, 2003

Niculiță, Nicolae 1999 - A. Niculiță, E. Nicolae, Le trésor de Brătușeni (Sărata Albă) dép. d'Edineț (XVIe siècle), in Arnăut, T., Zanoci, A., Matveev, S. (eds.), Studia in honorem Ion Niculiță. Omagiu cu prilejul împlinirii a 60 de ani, Cartdidact, 1999, 299-305.

Oța 2011 - S. Oța, Observații asupra cerceilor cu pandantive elipsoidale descoperiți pe teritoriul actual al României (sec. 14 - 15), Acta Mvsei Porolissensis 33 2011, 233-250.

Oța 2012 - S. Oța, Cercei decorați cu pandantive din granule (secolele 13 - 16) Studii și Cercetări de Istorie Veche (și Arheologie) 63/3-4, 2012, 269-292.

Oța 2020 - S. Oța, Podoabe, accesorii vestimentare și piese de mobilier funerar descoperite în necropola medievală de la Brad, județul Bacău, in Ursachi, V., Hânceanu, G. D., Simalcsik, A., Simalcsik, R. D., Munteanu, L. (eds.), Cimitirul medieval de la Brad. Cercetările arheologice din anii 1963 - 2004, Bibliotheca Archaeologica Moldaviae 27, Istros, 2020, 412-463

Oța et al. 2012 - S. Oța, A. Păunescu, Gh. Niculescu, M. Georgescu, Boucles d'oreille ayant un pendentif en fil entrelacé, Glasnik Srpskog arheološkog društva 27, 2012, 135-154.
Павлова 2007 - В. Павлова, Съкровищата на средновековна България, Археологически музей - Варна, 2007

Păunescu, Teodor 2006 - A. Păunescu, E. S. Teodor, La nécropole de Brănești Vadu Anei (le XVI-e siècle), Cercetări Arheologice 13, 2006, 275-307.

Păunescu et al. 2010 - A. Păunescu, I. Ene, D. Mihai, Gh. Matei, R. Coman, Cer cetări arheologice în vatra Orașului de Floci, (Piua Petri), comuna Giurgeni, județul Ialomița. Campaniile din anii 2008 - 2009, Cercetări Arheologice 17, 2010, 225-239.

Popa, Nicolae 1992 - L. Popa, E. Nicolae, Un tezaur de aspri otomani la începutul secolului al XVI-lea în colecțiile Muzeului Județean Brașov, Buletinul Societății Numismatice Române 80-85 1992, 139-154.

Popescu, Rosetti 1959 - D. Popescu, D. V. Rosetti, Săpăturile arheologice de la Retevoiești (r. Curtea de Argeș, reg. Pitești), Materiale și Cercetări Arheologice 6, 1959, 703-717.

Popescu et al. 1959 - D. Popescu, N. Constantinescu, Gh. Diaconu, S. Morintz, Șantierul arheologic Târgșor (r. și reg. Ploiești), Materiale și Cercetări Arheologice 6, 1959, 727-745

Премовић-Алексић 1985 - Д. Премовић-Алексић, Латинска црква у Постењу, Новопазарски зборник 9, 1985, 55-65.

Премовић-Алексић 1986 - Д. Премовић-Алексић, Средњовековна некропола у Глоговику, Новопазарски зборник 10, 1986, 27-41.

Премовић-Алексић 1988 - Д. Премовић-Алексић, Напреље - остаци средњовековне цркве И некрополе, Новопазарски зборник 12, 1988, 23-61.

Reabțeva 2014 - S. Reabțeva, Piese de podoabă și vestimentație din Moldova și Țara Românească în contextul relațiilor cultural-istorice (secolele 14 - 17), Istros, 2014

Réthy 1892 - L. Réthy, Adalékok a havaselvi vajdaság numismatikájához, Archaeologiai Értesítő 12, 1892, 433-436.

Rișcuța, Ferencz 2004 - C. Rișcuța, I. V. Ferencz, Noi cercetări arheologice și câteva considerații privind complexul ecleziastic de la Strei (jud. Hunedoara), Apulum 41, 2004, 337-366.

Rosetti 1972 - D. V. Rosetti, Tezaurul de podoabe medievale de la Olteni (Teleorman) și elementele lor bizantine, Buletinul Monumentelor Istorice 41/4, 1972, 3-14.

Spinei 1986 - V. Spinei, Săpăturile de la Trifești (jud. Iași), Materiale și Cercetări Arheologice 16, 1986, 237-242.

Spinei 1994 - V. Spinei, Moldova în secolele XI - XIV, Universitas, 1994.

Spinei, Popovici 1985 - V. Spinei, R. Popovici, Cercetările arheologice din necropola medievală de la Hudum, jud. Botoșani, Arheologia Moldoldovei 10, 1985, 74-88.

Stancu 2006 - P. Stancu, Monnaies découvertes dans la nécropole et l'établissement médiévale de Brănești-Vadu Anei, Cercetări Arheologice 13, 2006, 331-340.

Stuparu 1985 - C. Stuparu, Cercetări asupra așezării și necropolei feudale din secolele 14 - 15 din comuna Gruia, județul Mehedinți, Drobeta 6, 1985, 135-143

Tătaru 2019 - C. Tătaru, 7. ȚIfești, c. Țifești, j. Vrancea, România; toamna 1912, in Butnariu, V. M. (ed.) Moneta Terrae Moldaviae 2, Repertoriu tezaure, Stef, 2019, 219

Țeicu 2003 - D. Țeicu, Observații privind necropola medievală de la Turnu Severin, Studii Istorice, Mirton, 2003, 61-71.

Зечевић 2006 - Е. Зечевић, Накит Новог Брда. Из Археолошке збирке позног средњег века, Народни музеј у Београду, 2006. 